\title{
Using Movement Activities in Engaging Young Learners
}

\author{
Putu Eldina Iswandhary ${ }^{1 *}$ iD \\ ${ }^{I}$ English Language Education, Ganesha University of Education, Singaraja, Indonesia \\ *Corresponding author: eldina.iswandhary06@gmail.com
}

\begin{abstract}
Abstrak
Kegiatan termasuk gerakan dapat membuat pelajar muda memahami sesuatu melalui panca inderanya. Namun, alih-alih mengakomodasi mereka untuk belajar secara fisik, sebagian besar guru sering menyuruh pelajar muda untuk tetap diam di tempat duduk mereka. Oleh karena itu, artikel ini mengupas tentang bagaimana kegiatan gerak dapat digunakan oleh guru untuk melibatkan anak-anak didik di sekolah. Dalam penelitian ini, metode penelitian kepustakaan dilakukan dalam mengumpulkan data yang juga dianalisis oleh peneliti. Mengajar pelajar muda tidak semudah kelihatannya. Salah satu cirinya adalah suka belajar melalui aktivitas gerak yang dapat dilakukan dengan melihat, mendengar, menyentuh dan berinteraksi dengan sesuatu. Sayangnya, karakteristik ini juga dapat menjadi masalah bagi guru untuk melibatkan mereka dalam aktivitas kelas karena mereka dapat dengan mudah teralihkan pada hal-hal yang membuat mereka penasaran. Ada satu hal yang dapat dilakukan guru untuk membuat siswa terlibat di dalam kelas yaitu dengan menggunakan kegiatan gerak. Daripada mendorong siswa untuk diam dan diam, lebih baik memanfaatkan atau memanfaatkan karakteristik mereka sebagai cara untuk belajar. Beberapa kegiatan yang meliputi gerakan-gerakan seperti musik atau menyanyikan lagu dan bermain game dengan beberapa gerakan fisik, kegiatan respon fisik total, dan beberapa kegiatan lain yang melibatkan mewarnai, memotong, menempel, dan kegiatan gerakan lainnya dapat dilakukan oleh guru di dalam atau di luar ruangan. di luar kelas.
\end{abstract}

Kata kunci: Aktivitas Gerak, Menarik, Pembelajar Muda

\section{Abstract}

Activities including movements can make young learners understand something through their five senses. However, instead of accommodating them to learn physically, most of the teachers often tell young learners to stay still on their seat. Therefore, this article investigated on how movement activities can be used by the teachers to engage the young learners at school. In this study, library research method was conducted in collecting the data which is also analyzed by the researcher. Teaching young learners is not as easy as it seems. One of their characteristics is they like to learn through movement activities which can be done by seeing, hearing, touching and interacting with something. Unfortunately, this characteristic also can be a problem for teacher to engage them in the classroom activity since they can be easily distracted over things that they are curious about. There is one thing that the teacher could implement to make the students engage in the class which is by using movement activities. Instead pushing the students to stay still and keep silence, it is better to make use or utilize their characteristic as a way to learn. Some activities which are including movements like music or singing a song and playing games with some physical moves, total physical response activities, and some other activities which involve coloring, cutting, sticking, and any other movements activities could be done by the teacher inside or outside the classroom.

Keywords: Movement Activities, Engaging, Young Learners

$\begin{array}{ll}\text { History: } & \text { Publisher: Undiksha Press } \\ \text { Received : August 19, } 2021 & \text { Licensed: This work is licensed under } \\ \text { Revised : August20, } 2021 & \text { a Creative Commons Attribution 3.0 License } \\ \text { Accepted : October 04, } 2021 & \text { CC () O } \\ \text { Published : October 25, } 2021 & \end{array}$

\section{INTRODUCTION}

Teaching children is a very broad term since 'child' and 'childhood' cannot be fixed into strict age brackets (Parvin \& Salam, 2018; Sabirli \& Coklar, 2020). However, it is crucial to clarify what we mean by the concept of 'young learners' in terms of English language teaching. Young learners have been defined by a variety of scholars and researchers, focusing mainly on children of pre-school and primary school ages (Gilje, 2014; Rahayu, 2016). Even within this definition there are differences from country to other country. Young learner divided into three groups. The first is children who start pre-school at about the age of three, the second is the group of children who start primary school at around the age of 5-7 and finish primary school 11 or 12, although in some countries it happens at 
around the age of 13 or 14 . Pinter calls children from the age of 13 onwards 'early adolescents'.

As we know that English subject is mostly implemented early on from Kindergarten or Primary school. One of the reasons for teaching English since the early age is the convenience of their age for language acquisition (Bedir, 2019; Börekci \& Aydin, 2020). The belief that "younger is better" and children learn much more quickly and efficiently is generally appreciated by many especially by the supporters of Critical Period Hypothesis. Other reason for the popularity of teaching English to young learners is because it is a lingua franca nowadays which means that a common language used for communication between two people whose languages are different (Lee \& Coniam, 2013; Octaberlina \& Muslimin, 2020). Therefore, parents want their children to learn English as early as possible so that they will be able to benefit from English as an important part of their academic in the future.

In teaching young language learners, a number of reasons why children can benefit from learning a foreign language (Erdogan, 2019; Vo \& Nguyen, 2020). First, it can develop children's basic communication abilities in the language. Communication abilities need to be stimulated as early as possible. Teaching English also encourages enjoyment and motivation for language learning especially when it is in fun way (Erdogan, 2019). In addition, children can also promote learning about other cultures and develop children's cognitive skills as well as developing children's metalinguistic awareness. Learning language also means learning about the culture (Dizon, 2016; Tiwery, 2019). Therefore, to achieve those goals in English learning, teachers have the most important roles in creating an encouraging emotional atmosphere in the classroom for young learners. Different activities will support a statement. Teachers have to be creative in order to make a fun and interesting atmosphere in their class. Cooperative rather than the competitive atmosphere (especially including a winner and some physical reward) works better with young learners (Scott \& Ytreberg, 2001).

According to former Psychology professor James Asher, learning best occurs through physical action, such as pointing, touching, drawing, singing, miming and role-play. Movement activities are such a good way in teaching especially for young learners. Young learners are elementary students aged between 6-12 years old which also can be categorized into two groups which are the younger group from age 6-8 years and the older group which from age 9-12 years (Gilje, 2014; Kimsesiz, 2017). As young learners, they also have some different types of learning style which can be divided into three types which are visual, auditory, and kinesthetic learners. From those learning styles, kinesthetic learners are the one who often face by the teacher. Concerning characteristics of young learners, some children are creative and want to be active (Garton \& Fiona, 2018; Savic, 2014). Children in preschool or primary setting in generally learn by way of physical activities or learning by doing. It means that they learn through hands-on experiences and through manipulation of objects in the environment. Children's understanding comes not from the explanation, but from what they see and hear, and crucially, have a chance to touch and interact with. So, hands-on experiences and manipulation of objects in the environment can help young learners to understand something without explanation. Besides, being physically active every day is important for the healthy growth and the development of themselves.

Teaching young learners is not an easy thing to do (Artini, 2017; Muqarramah, 2016). One of the struggles in teaching young learners is that their attentions can be easily distracted which makes they do not want to stay still so the result is they will not be engaged with the lesson. Even if it is one of the problems which is faced by the teacher, but we cannot hide the fact that it is just how most of children act or behave. In reality, teacher often tells the students how to behave in a classroom by asking them to be quiet while the teacher is talking and raise their hands if they want $t$ do something. Instead of pushing them to stay still or quite, it is better to utilize what they have. Here it seems like young learners have so much 
energy which can be seen from their activeness in moving around, so it is better for the teacher to design or give them activities where they can explore and develop as much as possible.

One of the ways in teaching those young learners who are very active in moving around is by teaching them through some movement activities which could be conducted indoor or outdoor depends on the situation and kind of activities that the students will do. Based on the learning styles of children, classroom instruction should be "enjoyable and interesting; active and hands-on; supported and scaffolder; meaningful and purposeful; and culturally appropriate and relevant. So, it is important to make a relaxed and fun lesson for young learners, because students will perform better in their classes if they enjoy the class and have a good understanding in the lesson. Beside asking them to be quite and only listen to what is told by the teacher, it is better for the teacher to utilize or make use of their active physical movement in teaching. So this article will be discussed about how the teachers could engage the young learners at school through some movement activities. This article is aimed in helping the teacher to use movement activities at school for the students so that they could be engaged in the lesson.

\section{METHODS}

This research use a qualitative approach. This research is a library research, namely research conducted by searching for reading materials that are relevant to the topic. Literature study is all the efforts made by the author to collect information relevant to the topic or problem that will be or is being written (Lichtman, 2013). This information can be obtained from scientific books, research reports, scientific essays, theses and dissertations, regulations, regulations, yearbooks, encyclopedias, and other written sources both printed and electronic (Hamzah, 2019). Various information was collected from various sources such as books, papyrus, articles, research reports, and so on. Various information that has been collected is then reviewed, formulated, analyzed, and outlined in writing. Data collection is done by using documentation techniques, namely by reading, reviewing, studying, and noting the essence of the literature. This writing is descriptive in nature, namely the author describes systematically, factually and actually (Sugiyono, 2014).

\section{RESULTS AND DISCUSSION}

\section{Results}

Being physically active is very important for young learners, because by making physical activity a priority and encouraging good habits from an early age can help them to develop the skills they need to continue being active throughout their lives. Children are rapidly developing physically, cognitively, socially, and emotionally, so their experience with the physical environment can have long-lasting effects on their development. Children seem to learn language quickly and thoroughly when the brain and body work together. Therefore, movement activities make it possible to integrate physical exercise and play into language teaching quite naturally and to enhance children's physical activity. From those we can tell that the teacher should just let young learners become physically active as much as possible so that their behavior, academic performance, and development could be well developed. So, besides tailoring children's needs to engage in learning process, using movement activities also could enhance their developmental opportunities. Besides, these kinds of activities also could provide students in distributing their active energy.

In applying movement activities in the classroom, the instructor must first believe in its effectiveness and should seriously consider if it fits in with the students' interests and 
abilities. Next, the necessary resources to carry out this method should be taken into consideration, such as available space to perform the motor activities, songs or games that involve movement. Therefore, in order to conduct movement activities whether it is conducted indoor or outdoor, teacher should have a good classroom management skill first. If the activities were done indoor, teacher should consider what kind of movement activities which can be implemented, how much space they need, and many other things which need to be considered as in an indoor setting is commonly related to low access to natural daylight and fresh air. While if the activities were done outdoor, besides providing with more spacious space for young learners to move, it is also a major contributor to cognitive, motor, social and emotional development through touching, seeing and experiencing nature. Children health will be improved and the risk of sick building syndrome will be reduced during outdoor activity since young learners can yield in the sun. But, one thing that the teachers should understand when they use movement activity to teach young learners is that the activities should be changed constantly. Some activities which are including movements like music or singing a song and playing games with some physical moves, total physical response activities, and some other activities which involve coloring, cutting, and sticking are the activities which could be said as the best ways to ensure that students are engaged in the class.

The first movement activity that can be used both indoor and outdoor is 'Last One Standing' can be used by the teacher to teach vocabulary to young learners which is one of the games entitled "Using Games as a Tool in Teaching Vocabulary to Young Learners". So, this activity gives a chance for young learners to stand up and move their body a little bit. This activity is played while young learners are standing up in a circle and the teacher count to three and give out the topic. After that, the first student in the circle will have to give a word related to the topic and so on. Learner who cannot say a new word or repeat the words of the last student has to take a seat. The last student standing will be declared the winner. In this activity, students' sense of competition will develop in order to be the one last standing. When the young learners show their enthusiasm and focus throughout this activity, it means that the students are engage in the lesson.

Song also could be used as movement activities because of the music positive effects on brain growth and young learners' bodily system. Music reduces stress and enhances the function of the immune system which also affects the heart rate and blood pressure while improving blood flow. Children are being overexcited, the right song can be calming and relaxing. If children have been sitting down for a while, the right song can add energy and excitement to the class. The interaction between children and music progresses from rocking or clapping along with music as babies to engaging in "active listening" at about four years by singing, moving, and doing finger plays. They then move on to more advanced interaction, reproducing melodies, synchronizing movements with rhythm, and singing and moving with a group. Looking at this statement, it shows that children have been connected to music since they are still little or even in the mother's womb(Edwards et al., 2005). So it means that children have an innate kinesthetic sensibility to move to beats and rhythms and as they grew up their developmental stages of music and movement are interrelated.

\section{Discussion}

Applying games use competitive exercises which can allow students to challenge themselves to learn better or to compete against each other. It can also motivate young learners to learn and immerses them in the lesson so they can learn more effectively. Guessing game through movement is also one example of a good activity. Teacher can shows pictures or only word e.g. action word to one student, then that student should move the body in mimicking that word like a pantomime and the other students should guess what it is. So in 
this activity, every student has the same chance to mimicking the word given. They will also try their best to guess what kind of thing that their friend is trying to mimic. This activity also can give some information related to the word or picture given without being explained by the teacher. So, for example if the word shown is "walk", one student should mimic it by walking, and other student should answer that the word given is "walk". In Total Physical Response (TPR) Activities in Teaching English to Young Learners article, it shows that by learning new concepts through the body helps children understand the meaning without the teacher's explanation or translation, because children, especially when they are young or if the material is difficult, can better understand concepts when they use movement to physically act out the concepts (Alhassan, 2019; Ratminingsih et al., 2018).

Role play is also the best activity in expressing young learners' energy. It allows learners to take part in an experience by acting out the role of a character in a particular situation and experiencing empathy with that character. It also gives them a chance to move their body by speaking. Besides developing their physic, role play also takes role in developing their social interaction since they need to interact with each other. Teacher can give a topic to them and they can develop the story as they want since in that age, they have imagination which can be out of the box. Teacher just needs to let them be what they want to be. In this activity, young learners could use all of their five senses, so that this activity is actually the best activity which can be implemented by the teacher to accommodate the students' need. Research entitled The Effectiveness of Role Play in Teaching Speaking found out that role play is effective in teaching speaking. It means that, this activity not only gives young learners chance to move around, but they also seem engage in the learning process which can be seen in the result of that study. So, those movement activities above could be used by teacher in making input meaningful and comprehensible, reducing stress and engaging children affectively (Kimsesiz, 2017).

Therefore, it can be said that through movement activities, as children interact with objects and materials, with people, and with ideas and thoughts, the information gained through this experience is explored, tested, reflected upon and represented in a variety of ways. Teaching/learning through movement is a method through which children can cognitively, emotionally and physically benefit from. It has the ability to engage and motivate learners, especially younger ones. It also positively enhances the disposition of the learner; therefore, facilitating the learning process of listening, speaking, reading and writing. There are many other parts of the school day where physical movement and activities can be increased for young learners. Teachers and school staff can advocate for more movement interventions, strategies and programs outside of a gymnasium throughout the day. This could potentially be met through increased physical movement in grade level classes, encouraging longer and more active recess, as well and maximizing before and after school time.

\section{CONCLUSION}

Teaching young learners is not as easy as it seems. One of their characteristics is they like to learn through movement activities which can be done by seeing, hearing, touching and interacting with something. Unfortunately, this characteristic also can be a problem for teacher to engage them in the classroom activity since they can be easily distracted over things that they are curious about. There is one thing that the teacher could implement to make the students engage in the class which is by using movement activities. Instead pushing the students to stay still and keep silence, it is better to make use or utilize their characteristic as a way to learn. Some activities which are including movements like music or singing a song and playing games with some physical moves, total physical response activities, and 
some other activities which involve coloring, cutting, sticking, and any other movements activities could be done by the teacher inside or outside the classroom.

\section{REFERENCES}

Alhassan, A. (2019). Investigating business EFL postgraduate student writing in a UK university: a qualitative study. Cogent Education, 6(1). https://doi.org/10.1080/2331186X.2019.1699741.

Artini, L. P. (2017). Rich Language Learning Environment and Young Learners' Literacy Skills in English. Lingua Cultura, 11(1), 19-24. https://doi.org/10.21512/lc.v11i1.1587.

Bedir, H. (2019). Pre-service ELT teachers' beliefs and perceptions on 21 st century learning and innovation skills (4Cs). Journal of Language and Linguistic Studies, 15(4), 231246. https://doi.org/10.17263/j1ls.547718.

Börekci, R., \& Aydin, S. (2020). Foreign language teachers' interactions with their students on Facebook. Computer Assisted Language Learning, 33(3), 217-239. https://doi.org/10.1080/09588221.2018.1557691.

Dizon, G. (2016). A comparative study of Facebook vs. paper-and-pencil writing to improve L2 writing skills. Computer Assisted Language Learning, 29(8), 1249-1258. https://doi.org/10.1080/09588221.2016.1266369.

Edwards, L. C., Bayless, K. M., \& Ramsey, M. E. (2005). Music, a Way of Life for the Young Child 5th Edition. Pearson College Div; 5th edition.

Erdogan, V. (2019). Integrating 4C Skills of 21st Century into 4 Language Skills in EFL Classes Vacide Erdoğan. International Journal of Education and Research, 7(11), 113-124.

Garton, S., \& Fiona, C. (2018). The Routledge handbook of teaching English to young learners. Routledge. https://doi.org/10.4324/9781315623672.

Gilje, T. M. (2014). Teacher Cognition and The Teaching of EFL Reading in Norwegian Upper Primary Classrooms. Acta Didactica Norge, 8(2), 1-17. https://doi.org/10.5617/adno.1141.

Hamzah, A. (2019). Metode Penelitian Kepustakaan: Kajian Filosofis, Teoretis, dan Aplikatif. Literasi Nusantara.

Kimsesiz, F. (2017). The Effect of Project Based Learning in Teaching EFL Vocabulary to Young Learners of English: The Case of Pre-School Children. Online Submission, 5(4), 426-439. https://eric.ed.gov/?id=ED581572.

Lee, I., \& Coniam, D. (2013). Introducing assessment for learning for EFL writing in an assessment of learning examination- driven system in Hong Kong. Journal of Second Language Writing, 22(1), 34-50. https://doi.org/10.1016/j.jslw.2012.11.003.

Lichtman, M. (2013). Qualitative Research in Education (3rd ed.). SAGE Publications.

Muqarramah. (2016). Pendekatan Student Centered Learning; Design Pembelajaran Aqidah Akhlak. Jurnal Tarbiyah (Jurnal Ilmiah Kependidikan), 5(2), 23-43. https://doi.org/10.18592/tarbiyah.v5i2.982.

Octaberlina, L. R., \& Muslimin, A. I. (2020). EFL Students Perspective towards Online Learning Barriers and Alternatives Using Moodle/Google Classroom during COVID19 Pandemic. International Journal of Higher Education, 9(6), 1. https://doi.org/10.5430/ijhe.v9n6p1.

Parvin, R. H., \& Salam, S. F. (2018). The Effectiveness of Using Technology in English Language Classrooms in Government Primary Schools in Bangladesh. FIRE: Forum for International Research in Education, 2(1). https://doi.org/10.18275/fire201502011049. 
Rahayu, V. W. T. (2016). Teachers' Challenges in Teaching English to Young Learners in Rural Public Primary Schools in Salatiga. Universitas Kristen Satya Wacana.

Ratminingsih, N. M., Mahadewi, L., \& Divayana, D. (2018). ICT-Based Interactive Game in TEYL: Teachers' Perception, Students' Motivation, and Achievement. International Journal of Emerging Technologies in Learning, 13(9), 190-203.

Sabirli, Z. E., \& Coklar, A. N. (2020). The Effect of Educational Digital Games on Education, Motivation and Attitudes of Elementary School Students Against Course Access. World Journal on Educational Technology: Current Issues, 12(3), 175. https://doi.org/10.18844/wjet.v12i3.4993.

Savic, V. M. (2014). Total Physical Response (TPR) Activities in Teaching English To Young Learners. Физичка Култура И Модерно Друштво, Пос. Изд, Кю., 17(September), 447-454.

Scott, W. A., \& Ytreberg, L. H. (2001). Teaching English to Children (14th Ed.) (14th ed.). Longman.

Sugiyono. (2014). Metode Penelitian Pendidikan Pendekatan Kuantitatif, Kualitatif, dan $R \& D$. Alfabeta.

Tiwery, S. D. (2019). Inside-Outside Circle As the Way in Building Students' Motivation and Interaction in Speaking Classroom Activities. International Journal of Language Education, 1(1), 33. https://doi.org/10.26858/ijole.v1i1.6703.

Vo, L. T., \& Nguyen, H. T. M. (2020). Critical friends group for EFL professional development. ELT Journal, 64(2), 205-213. https://doi.org/10.1093/elt/ccp025. 